\title{
Effect of Hyperinsulinemia on the Development of Blood Coagulation in the Lamb Fetus
}

\author{
C. THOMAS KISKER AND MARILYN MANCO-JOHNSON \\ Department of Pediatrics. University of Iowa College of Medicine, Iowa City, Iowa [C.T.K.] \\ Pediatric Hematology, University of Colorado Health Sciences Center. Denver, Colorado [M.M.-J.I
}

\begin{abstract}
Infants of diabetic mothers have an increased risk for thrombosis. The etiology of their hypercoagulable state is unknown. To examine the effects of hyperinsulinemia on the development of coagulation during fetal life, 10 sets of chronically catheterized fetal lambs were studied. One twin from each pair of 120-d gestation lamb fetuses was infused with insulin at a rate of 2.5 $\mathrm{U} / \mathrm{h}$ for $48 \mathrm{~h}$, whereas its twin sibling was infused with an equal volume $(20 \mathrm{mI}$.) of dextrose $5 \%$ in water. Changes in coagulation factor activities were measured before and after the infusions, and differences were analyzed by paired $t$ tests. There was a significant decrease in protein $(:$ after insulin treatment in the
\end{abstract}

ABSTRACT
Infants of diabetic mothers have an increased incidence of both arterial and venous thromboses. Oppenheimer and Fsterly (1) reported a $15.8 \%$ incidence of venous thrombosis in 4.5 newborn infants of diabetic mothers. Renal vein thrombosis is the most common thrombotic complication in infants of diabetic mothers $(2,3)$. More recently, Van Allen et al. (4) first reported an infant of a diabetic mother with an in utero brachial artery thrombosis and neonatal gangrene who developed postnatal aortic and mesenteric artery thrombosis. After review of the literature, they found that 7 of 32 infants with neonatal gangrene of a limb presenting at birth were infants of diabetic mothers. David et al. (5) reported a case of oromandibular limb hypogenesis thought to be associated with an intrauterine vascular accident in an infant of a diabetic mother.

The hemostatic alterations predisposing to thrombosis and the specific factors responsible for these alterations are unclear. Hemostatic alterations found in infants of diabetic mothers who experience a thrombotic event could simply be secondary to the thrombotic event. There could also be primary alterations of the normal development of homeostasis in these infants exposed to both hyperglycemia and hyperinsulinemia during intrauterine life leading to a hypercoagulable state. The chronically catheterized fetal lamb provides a model whereby

Received May 16. 1994: accepted April 6, 1995

Correspondence and reprint requests: (C. Thomas Kisker, M.D., University of Iowa College of Medicine. Department of Pediatrics-2520 JCP, 200) Hawkins Drive, Iowa City, IA $52242-1083$

Supported by VIH Grant 2R01 HD12574 insulin-treated twins. There were relative increases in fibrinogen factors V, VII, and XI when the insulin-treated group was compared with the controls. The changes are consistent with an increased risk of thrombosis and may explain, in part, the higher incidence of thrombosis in infants of diabetic mothers. (Pediatr Res 38: 169-172, 1995)

\author{
Abbreviations \\ $\mathbf{D}_{5} \mathbf{W}$, dextrose $5 \%$ in water solution \\ WBC, white blood cell
}

the intrauterine environment can be altered and the effects measured. Using twin lamb fetuses, it is possible to modify the environment of one fetus while allowing the other fetus to serve as control. This model was used successfully in studies of the effects of glucocorticoids and thyroxin on the development of hemostasis in the fetus $(6,7)$. We have, therefore, undertaken similar studies to measure the effects of hyperinsulinemia on the development of hemostasis in fetal lambs during the last trimester of pregnancy.

\section{METHODS}

Pregnant mixed-breed Dorset-Suffolk ewes were obtained from existing sources and were housed throughout the study at the University of Iowa Animal Quarters. The gestational ages of the fetuses were known on the basis of induced ovulation technique (8). Before surgery the ewes were fasted for $48 \mathrm{~h}$. Anesthesia of the ewe and surgery on the fetus were performed as described previously (9)

Ten pregnant ewes each with twin pregnancies were used in this study. The gestational ages of the twins averaged $120 \mathrm{~d}$ (109-130 d). Twins were used to control for natural intrauterine environmental differences. Both fetuses in each pregnant ewe were catheterized. Arterial and venous catheters were placed in the femoral arteries and veins of each of the twins. After a 5-d rest period, one of each set of twins was infused i.v. with insulin in $\mathrm{D}_{5} \mathrm{~W}$ at a rate of $2.5 \mathrm{U} / \mathrm{h}$ for $48 \mathrm{~h}$. The twin sibling was infused with an equal volume $(10 \mathrm{~mL} / 24 \mathrm{~h})$ of 
$\mathrm{D}_{5} \mathrm{~W}$. Constant infusion pumps (Cormed, Inc., Middleport, NY) were used for the infusions. Both micropumps were housed in pockets of special jackets designed by our laboratory which allow the ewes complete freedom of movement during the infusions.

Before and at the completion of the infusions at $48 \mathrm{~h}$, fetal blood samples were obtained through the chronically placed catheters for measurements of coagulation factor activities in both test and control fetuses. A 7-mL aliquot of blood was obtained from each fetus with each phlebotomy. All samples were collected in plastic, and samples for measurement of coagulation factor activities were diluted 9 parts of blood to 1 part of $0.01 \mathrm{M}$ sodium citrate, $\mathrm{pH} 5.0$. Blood samples were centrifuged at $1800 \times \mathrm{g}$ for $30 \mathrm{~min}$; the supernatant plateletpoor plasma was removed, stored at $-70^{\circ} \mathrm{C}$ in aliquots, and thawed just before measurement of clotting factor activities.

Standard techniques were used for measuring the prothrombin time (10) and the partial thromboplastin time (11). Specific factor activities II, V, VII, VIII, IX, X, XI, and XII were assayed with the one-stage assays measuring the ability of the test plasma to correct plasma known to be deficient in the factors tested (12). Fibrinogen was measured by thrombin clotting time according to the method of Clauss (13). Human deficient plasmas were used, and an adult sheep standard pool consisting of plasma from 10 normal nonpregnant ewes was used for calibration. Antithrombin III was measured by the method of Henriksen and Owen (14). Plasminogen was measured using the amidolytic method described by Mussoni et al. (15). Protein C activity was measured as described with Laurell rocket immunoelectrophoresis using a monospecific polyclonal rabbit anti-ovine protein $\mathrm{C}$ antibody (our unpublished experi- ment). Fibrin monomer was measured by the method of Kisker (16). All activities measured are quoted as percentage of the reference standard pool of sheep plasma. Insulin levels were measured by RIA kit (Diagnostic Products Corp., Los Angeles, CA). The hemoglobin, hematocrit, and WBC count were measured with a Coulter model S (Coulter Electronics, Inc., Hialeah, FL) on a $0.5-\mathrm{mL}$ aliquot of blood that was anticoagulated with EDTA. Platelet counts were measured by phase microscopy on this EDTA sample.

The differences before and after insulin or saline infusion in each group and the differences between groups before and after insulin or saline infusions were statistically analyzed using paired $t$ tests.

\section{RESULTS}

In Table 1 are presented the means and standard deviations of coagulation factor activities, hematocrit, WBC counts, platelet counts, insulin levels, and serum glucose concentrations before and after insulin infusion in control and treated twin pairs. The $p$ values for the differences before and after treatment in each group are presented and the between group before and after treatment $p$ values are also included.

Figure 1 shows that protein $\mathrm{C}$ significantly decreased after insulin infusion in the insulin treated group. In the insulintreated animals, as shown in Figure 1, the level of protein $\mathrm{C}$ decreased from 64 to $44 \%$ ( $p=0.003$ ), whereas in the control animals the level decreased from 66 to $56 \%(p=0.141)$. The between group differences did not, however, reach statistical significance $(p=0.0895)$. As expected, insulin also showed a statistically significant increase within the insulin-treated group

Table 1. Treatment results

\begin{tabular}{|c|c|c|c|c|c|c|c|}
\hline \multirow[b]{2}{*}{ TEST } & \multicolumn{2}{|c|}{ Insulin $(n=10)$} & \multirow{2}{*}{$\begin{array}{c}\mathrm{B}-\mathrm{A}^{*} \\
p=\end{array}$} & \multicolumn{2}{|c|}{ Control $(\mathrm{n}=10)$} & \multirow{2}{*}{$\begin{array}{c}\mathrm{B}-\mathrm{A} \dagger \\
p=\end{array}$} & \multirow{2}{*}{$\begin{array}{c}\text { GROUP } \neq \\
p=\end{array}$} \\
\hline & Before & After & & Before & After & & \\
\hline Prothrombin time (s) & $16.3 \pm 1.2$ & $16.2 \pm 1.3$ & 0.812 & $16.9 \pm 2.0$ & $16.8 \pm 1.5$ & 0.960 & 0.8605 \\
\hline Partial thromboplastin time (s) & $70.9 \pm 21.9$ & $61.3 \pm 12.8$ & 0.250 & $74.8 \pm 21.9$ & $70.0 \pm 13.9$ & 0.556 & 0.1105 \\
\hline Thrombin time (s) & $17.4 \pm 2.9$ & $19.4 \pm 4.7$ & 0.282 & $17.2 \pm 2.5$ & $17.9 \pm 2.8$ & 0.554 & 0.4445 \\
\hline Fibrinogen (mg/dl) & $108.9 \pm 14.8$ & $109.4 \pm 13.7$ & 0.938 & $118.7 \pm 22.7$ & $108.5 \pm 17.9$ & 0.276 & 0.0153 \\
\hline Factor II $(\%)$ & $33.8 \pm 6.24$ & $33.14 \pm 9.27$ & 0.860 & $32.1 \pm 6.7$ & $30.1 \pm 7.3$ & 0.526 & 0.4952 \\
\hline Factor VII $(\%)$ & $44.2 \pm 8.34$ & $49.6 \pm 9.3$ & 0.196 & $48.5 \pm 7.1$ & $46.3 \pm 6.9$ & 0.497 & 0.0399 \\
\hline Factor VIII $(\%)$ & $30.92 \pm 9.4$ & $32.6 \pm 11$ & 0.712 & $31.9 \pm 11.9$ & $33.8 \pm 16.3$ & 0.770 & 0.9591 \\
\hline Factor IX $(\%)$ & $30.4 \pm 8.2$ & $30.1 \pm 8.4$ & 0.943 & $28.7 \pm 5.6$ & $27.1 \pm 8.4$ & 0.623 & 0.6223 \\
\hline Factor $\mathrm{X}(\%)$ & $30.2 \pm 4.2$ & $27.8 \pm 7.1$ & 0.372 & $31.3 \pm 6.3$ & $26.9 \pm 4.9$ & 0.097 & 0.3544 \\
\hline Factor XI $(\%)$ & $53.9 \pm 21.8$ & $59.1 \pm 22.5$ & 0.608 & $58.8 \pm 28.5$ & $47.7 \pm 16.1$ & 0.298 & 0.0063 \\
\hline Factor XII $(\%)$ & $42.5 \pm 10.9$ & $44.4 \pm 11.2$ & 0.708 & $43.1 \pm 13.1$ & $42.7 \pm 18.3$ & 0.947 & 0.4998 \\
\hline von Willebrand factor $(\%)$ & $10.8 \pm 7.5$ & $10.2 \pm 7.5$ & 0.866 & $11.5 \pm 8.3$ & $10.9 \pm 8.9$ & 0.871 & 0.9169 \\
\hline Protein C $(\%)$ & $63.9 \pm 12.4$ & $44.0 \pm 13.1$ & 0.003 & $65.9 \pm 16.6$ & $56.2 \pm 10.9$ & 0.141 & 0.0895 \\
\hline Plasminogen $(\%)$ & $50.3 \pm 7.7$ & $51.06 \pm 8.9$ & 0.838 & $48.3 \pm 6.7$ & $52.6 \pm 8.2$ & 0.201 & 0.1673 \\
\hline Fibrin monomer & $1.6 \pm 2.1$ & $2.0 \pm 2.1$ & 0.673 & $1.6 \pm 2.1$ & $2.0 \pm 2.1$ & 0.673 & 1.0000 \\
\hline Hematocrit & $32.5 \pm 4.4$ & $33.2 \pm 4.4$ & 0.734 & $30.8 \pm 4.9$ & $32.5 \pm 4.5$ & 0.430 & 0.5947 \\
\hline WBC & $3240 \pm 1088$ & $3660 \pm 1359$ & 0.456 & $2990 \pm 664$ & $3340 \pm 729$ & 0.276 & 0.8310 \\
\hline Platelet & $389.0 \pm 103.7$ & $403.8 \pm 141.9$ & 0.465 & $488.5 \pm 224.2$ & $497.4 \pm 211.6$ & 0.276 & 0.9496 \\
\hline Insulin & $7.8 \pm 5.1$ & $220.6 \pm 111.6$ & 0.000 & $8.3 \pm 6.2$ & $8.9 \pm 6.8$ & 0.863 & 0.0002 \\
\hline Glucose & $13.0 \pm 7.5$ & $12.1 \pm 14.0$ & 0.863 & $19.7 \pm 24.0$ & $16.0 \pm 14.6$ & 0.679 & 0.7185 \\
\hline
\end{tabular}

Results are presented as mean values $\pm 1 \mathrm{SD}$.

${ }^{*} p$ values, $t$ test for differences before and after insulin infusion.

$\dagger p$ values, $t$ test for differences before and after control saline infusion.

$\$ p$ values, paired $t$ test for differences between groups before and after insulin. 


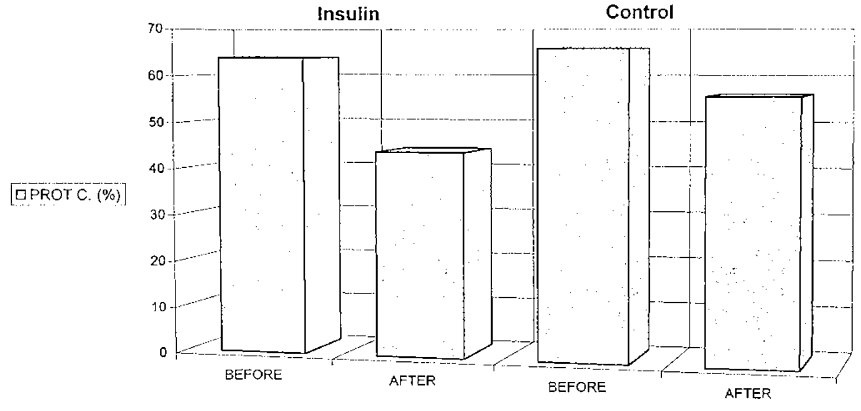

Figure 1. Protein $\mathrm{C}$ in fetal lambs before and $48 \mathrm{~h}$ after insulin and control treatment.

before and after treatment from a mean of $7.84 \mathrm{U}$ to a mean of $220.6 \mathrm{U}(p=0.0010)$.

Fibrinogen and factors V, VII, and XI significantly increased in the insulin-treated group when compared with the control group. There were, however, no significant changes in these factors within the insulin or control groups.

\section{DISCUSSION}

Blood coagulation factor activities, particularly the vitamin $\mathrm{K}$-dependent factors including protein $\mathrm{C}$, are low in newborn infants relative to adult standards (17-20). These deficiencies render the neonate at risk for developing either hemorrhage or thrombosis with minimal hemostatic stress.

Previous studies using a fetal lamb model have shown that the patterns of development of blood coagulation factor activities in the model are similar to those identified in the human infant (9). Major increases in many of the blood coagulation factor activities occur toward the end of the last trimester of pregnancy (9). Hormones may influence the normal patterns of development of coagulation factor activities and thus increase the likelihood of hemorrhage or thrombosis in the newborn. We previously reported a study of the effects of a 48 -h infusion of glucocorticoids in the fetal lamb model. In this study, a 48-h exposure to increased glucocorticoids accelerated the development of coagulation factors (II, V, VII, IX, and X). More recently, a study of the effects of thyroxin demonstrated decreases in factor V and VII and increases in factor XII in thyroxin-treated fetal lambs (7).

A number of physiologic disorders in infants of diabetic mothers have been suggested as possible contributing factors to the development of thrombosis in these infants. These disorders include dehydration, polycythemia, increased platelet prostaglandin synthesis, and decreased fibrinolysis $(1,21,22)$. A decrease in the anticoagulant protein $\mathrm{C}$ has also been suggested as potential factor leading to thrombosis. In a recent prospective survey of 193 newborn infants, protein C levels $<0.1 \mathrm{U} / \mathrm{mL}$ were found in preterm infants with respiratory distress, infants of diabetic mothers, and infants of twin gestations (23). A protein C level $<0.1 \mathrm{U} / \mathrm{mL}$ correlated with the subsequent onset of thrombosis even when the effects of gestational age and birth weight were excluded.

In the current studies fetal lambs were exposed to hyperinsulinemia using the protocol that had previously been successful in demonstrating changes in blood coagulation factors in fetal lambs exposed to glucocorticoids. In the current study we demonstrated a decrease in the level of protein $\mathrm{C}$ (mean = $63.9 \%$ before insulin, mean $=44.0 \%$ after insulin, and minimum $=25 \%, p=0.003)$. The mean level $(44 \%)$ has been associated with thrombosis in adults (24). The relative increases in fibrinogen and factors V, VII, and XI in the insulintreated fetuses compared with their twin sibling controls are unexplained. In each case these factor levels increased in the insulin-treated fetuses, whereas the levels decreased in the control fetuses. However, none of the within group changes was significant. The volume of sample removed and the rate of infusion of saline or insulin was equal in both groups, and neither was sufficient to account for the decreased levels; there was no decrease in the hematocrit to suggest dilutional changes. The relative increases in fibrinogen and factors $\mathrm{V}$, VII, and XI coupled with the low protein $C$ levels all tend to shift the balance of hemostasis toward thrombosis. There were no counterbalancing decreases in the levels of other procoagulants or increases in the levels of other anticoagulants in the insulin-treated group which would shift the balance toward hemorrhage.

Unfortunately, not all factors predisposing to thrombosis could be measured in this experimental model. Because of the limitations on the volume of sample available, we were not able to measure the levels of free protein $S$, a cofactor of protein $\mathrm{C}$. An increase in tissue factor pathway inhibitor might counterbalance the relatively increased levels of factors $\mathrm{V}$ and VII in the insulin-treated animals, but we were also unable to measure tissue factor pathway inhibitor in the fetal lambs. Despite these deficiencies, the findings demonstrated that exposure of the fetus in utero to hyperinsulinemia for $48 \mathrm{~h}$ results in alterations of the balance of hemostasis toward thrombosis.

\section{REFERENCES}

1. Oppenheimer EH, Esterly JR 1965 Thrombosis in the newborn: Comparison between diabetic and nondiabetic mothers. J Pediatr 67:549-556

2. Avery ME, Oppenheimer EH, Gordon HH 1957 Renal-vein thrombosis in newborn infants of diabetic mothers: Report of 2 cases. N Engl J Med 256:1134-1138

3. Takeuchi A, Berirschke K 1961 Renal venous thrombosis of the newborn and its relation to maternal diabetes. Report of 16 cases. Biol Neonate 3:237-256

4. Van Allen MI, Jackson JC, Knopp RH, Cone R 1989 In utero thrombosis and neonatal gangrene in an infant of a diabetic mother. Am J Med Genet 33:323-327

5. David A, Rozé JC, Rémond S, Branger B, Héloury Y 1992 Hypoglossia-hypodactylia syndrome with jejunal atresia in an infant of a diabetic mother. Am J Med Genet 43:882-884

6. Kisker CT, Robillard JE, Bohlken DP 1983 Glucocorticoid stimulation of blood coagulation factor activities in the fetal lamb. J Lab Clin Med 101:569-575

7. Kisker CT, Bohlken D, Clarke WR 1993 Thyroxine and fetal blood coagulation: A fetal lamb study. J Dev Physiol 19:57-59

8. Ainsworth L, Hackett A, Heaney D, Longford G, Peters H 1977 A multidisciplinary approach to the development of controlled breeding and intensive production systems for sheep. From the symposium, Management of Reproduction in Sheep and Goats. Madison, WI.

9. Kisker CT, Robillard JE, Clarke WR 1981 Development of blood coagulation: A fetal lamb model. Pediatr Res 15:1045-1050

10. Tocantins LM 1964 Estimation of prothrombin (one-stage method of Quick). In: Tocantins L, Kayal E (eds) Blood Coagulation, Hemorrhage and Thrombosis: Mcthods of Study. Grune \& Stratton, New York, p 148

11. Proctor RR, Rapaport SI 1961 The partial thromboplastin time with kaolin: A simple screening test for first stage plasma clotting factor deficiencies. Am J Clin Pathol $36: 212-219$

12. Owen CA, Bowie EJW, Didishcim P, Thompson JH 1969 Tests of hemostasis and blood coagulation. In: Cawley LP (eds) The Diagnosis of Bleeding Disorders. Little, Brown \& Co., Boston, pp 71-112

13. Clauss VA 1957 Gerinnungphysiologische Schnellmethode zur Bestimmunmg des Fibrinogens. Acta Haematol 17:929-942 
14. Henriksen RA, Owen WE 1976 The use of an improved assay to measure heparin cofactor levels in normal individuals and patients with malignancies. Fed Proc 35:2907(abstr).

15. Mussoni L, Raczka E, Chmiclewska J, Donati MB, Latallo ZS 1979 Plasminogen assay in rabbit, rat and mouse plasma using the chromogenic substrate S-2251. Thromb Res 15:341-349

16. Kisker CT 1979 Detection of fibrin monomer: Comparison of the immune precipitate method with the serial dilution protaminc sulfate test and the ethanol gelation test. Am J Clin Pathol 72:405-409

17. Bleyer WA, Hakami J, Shephard T 1971 The development of hemostasis in the human infant. J Pediatr 79:838-853

18. Hathaway WE, Bonnar J 1978 Physiology of coagulation in the fetus and newborn infant. In: Perinatal Coagulation. Grune \& Stratton, New York, pp 53-80

19. Jensen AH, Josso F, Zamet P, Monsat-Couchard M, Minkowski A 1973 Evolution of blood clotting factor levels in premature infants during the first 10 days of life: A study of 96 cases with comparison between clinical status and blood clotting factor levels. Pediatr Res 7:638-644

20. Van Teunenbroek A 1990 Protein C activity and antigen levels in childhood. Eur J Pediatr 149:774-778

21. Ambrus CM, Ambrus JL, Courey N, Moscovich L, Bruck E, Allen J, June O, Mirand E, Niswander K 1979 Inhibitors of fibrinolysis in diabetic children, mothers and their infants. Am J Hematol 7:245-254

22. Stuart MJ, Sunderji SG, Allen JB 1989 Decreased prostacyclin production in the infant of the diabetic mother. J Lab Clin Med 98:412-416

23. Manco-Johnson MJ, Abshire TC, Jacobson LJ, Marlar RA 1991 Severe neonatal protein $\mathrm{C}$ deficiency: Prevalence and thrombotic risk. J Pediatr 119:793-798

24. Allaart CF, Poort SR, Rosendaal FR, Reitsma PH, Bertina RM, Briët E 1993 Increased risk of venous thrombosis in carriers of hereditary protein $\mathrm{C}$ deficiency defect. Lancet 341:134-138 